\title{
PENGAJARAN JIHAD DALAM KITAB FATH AL-BARI
}

\author{
Oleh: \\ Muhammad Amin ${ }^{1}$
}

\begin{abstract}
Jihad is one of the Islamic studies. In Fath Al-Bari book explained that jihad is to exert all abilities to fight the infidels. In other side, Jihad is also used in fighting the lust, evil and wicked person. Jihad in fighting the lust is through learning religion, practice and teaching it. Then, Jihad in fighting Satan or evil is by rejecting all (doubtful and lust) of his whisper. Meanwhile, jihad in fighting the evil is can be done by using property, verbal, and heart. The last Jihad in fighting the wicked person is by using verbal and heart.
\end{abstract}

Keyword: Learning, Jihad, Holy Book

\section{PENDAHULUAN}

Pembahasan tentang jihad sangat urgen (penting) dalam Islam. Hal ini dapat diketahui dari banyaknya ayat-ayat Alquran dan Hadis Nabi yang membicarakan masalah ini. Di antara kitab Hadis yang membicarakan tentang masalah ini adalah Imam Bukhari. Dia membuat kitab dan bab tersendiri dalam kitab sahihnya, yaitu pada kitab yang ke 56 yaitu Kitab al-Jihad wa al-Siyar dengan pembahasan bab sebanyak 199 bab.

Makna jihad yang pada dasarnya bersungguh-sungguh, tetapi dalam implementasi beragam bentuk ditemukan. Ada jihad dalam bentuk berjihad dengan diri (nyawa), jihad dengan harta (mal), Jihad mengendalikan nafsu, dan dalam bentukbentuk lain.

Dari banyaknya ayat dan hadis serta beragamnya bentuk jihad, menunjukkan bahwa jihad tersebut memiliki arti penting dalam ajaran Islam. Islam sebagai agama dakwah mengajak kepada kebaikan dan meninggalkan kemungkaran (keburukan), merupakan bentuk jihad dalam Islam. Oleh karena itu, makna pemahaman jihad dalam perspektif hadis perlu untuk di kupas secara mendalam melalu kajian yang khusus.

Hadis-hadis dalam kitab Sahih Bukhari, telah banyak disyarah oleh ulama hadis. Salah satunya adalah Fat¥ al-B $\pm r^{3}$ bi Syar¥ $\phi a z^{3} ¥ a l-B u k h \pm r^{3}$ yang di syarahkan oleh Ibn 'ajar al-'Asqal $\pm \mathrm{n}^{3}$. Pembahasan ini bertujuan bagaimana Imam Ibn Hajar mengupas tentang masalah al-Jihad wa al-Siyar di dalam kitabnya, sekaligus pola-pola pensyarahan dalam mengupas suatu matan hadis.

Makalah yang di hadapan pembaca ini mengupaskan tentang permasalahan

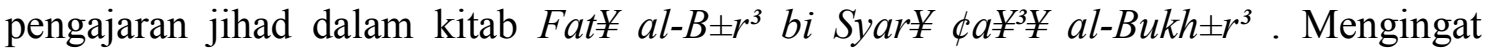
luasnya pembahasan ini maka di sini akan di bahas tentang pengertian jihad, Keutamaan Jihad dan Perjalanan hidup Nabi, Manusia yang paling utama adalah mukmin yang berjihad di jalan Allah dengan diri dan hartanya.

${ }^{1}$ Penulis Adalah Dosen FDIK IAIN Padangsidimpuan, Gmail: muhammad.amin7010@gmail.com 


\section{PEMBAHASAN}

\section{A. Pengertian Jihad}

Dari segi bahasa, kata jihad berasal dari bahasa Arab, bentuk isim masdar dari fi'il jahada, artinya mencurahkan kemampuan. Dalam Kamus al-Munjid fi al-Lughat wa alA'lam menyebutkan lafal jahada al-'Aduwwa, artinya qatalahu muhammatan 'aniddin (menyerang musuh dalam rangka membela agama). ${ }^{2}$

Secara istilah beragam makna dikemukakan oleh para pakar, diantaranya adalah Hasan al-Banna yang dikutip oleh Yusuf al-Qardawi mengatakan, jihad adalah suatu kewajiban Muslim yang berkelanjutan hingga hari kiamat, tingkat terendahnya berupa penolakan hati atas keburukan atau kemungkaran, dan yang tertinggi adalah perang di jalan Allah. Diantara keduanya adalah perjuangan dengan lisan, pena, tangan berupa pernyataan tentang kebenaran di hadapan penguasa yang zalim. ${ }^{3}$

Ibn Manzur dalam Lisan al-'Arab menulis jihad adalah memerangi musuh, mencurahkan segala kemampuan dan tenaga berupa kata-kata, perbuatan, atau segala yang di mampui. ${ }^{4}$ Ar-Raghib al-Asfahani mengatakan bahwa jihad mengerahkan kemampuan dalam menahan serangan musuh. Ia menambahkan bahwa jihad ada tiga macam, yakni berjuang menghadapi atau melawan musuh yang tampak, berjuang melawan syaitan, dan berjuang menghadapi hawa nafsu. Perjuangan tersebut dilakukan dengan tangan dan lisan. ${ }^{5}$

Ibn Hajar sendiri dalam kitab Fath al-Bari menulis jihad menurut bahasa berarti "Kesulitan". Dikatakan "Jahadtu jihadan", artinya saya mendapat kesulitan. Adapun menurut syariat adalah mengerahkan segala kemampuan untuk memerangi kaum Kafir. Lebih lanjut ia menjelaskan bahwa jihad juga digunakan dalam arti melawan hawa nafsu, Syaitan dan orang Fasik. Jihad melawan hawa nafsu adalah dengan belajar masalah agama, mengamalkan dan mengajarkannya. Sedangkan jihad melawan Syaitan adalah menolak semua apa (syubhat dan hawa nafsu) yang di bisikannya. Adapun jihad dalam arti melawan orang Kafir dapat dilakukan dengan kekuatan harta, lisan, dan hati. Sementara jihad melawan orang fasik adalah dengan kekuatan lisan dan hati. ${ }^{6}$

\section{B. Hadis Jihad dalam Fath al-Bari}

1. Hadis-Hadis tentang Jihad dalam Fath al-Bari.

Dalam kitab Fath al-Bari terdapat pembahasan khusus tentang jihad, yaitu Kitab al-jihad wa al-Siyar, dengan pembahasan sebanyak 199 bab. Karena begitu luasnya pembahasan jihad ini, penulis hanya membatasi pada dua bagian saja yaitu Keutamaan Jihad dan Perjalanan hidup Nabi, Manusia yang paling utama adalah mukmin yang berjihad di jalan Allah dengan diri dan hartanya.

${ }^{2}$ Abu Luois Maqluf, Al-Munjid fi al-Lugah wa al- 'alam, (Beirut: Dar al-Masriq, 1986), h. 106

${ }^{3}$ Yusuf Qardhawi, Pendidikan Islam dan Madrasah Hasan al-Banna, Diterjemahkan Bustami A.Ghani dan Zainal Abidin Ahmad, (Jakarta: Bulan Bintang, 1980), h.74

${ }^{4}$ Ibn Manzur, Lisan al- 'Arab al-Muhith, (T.Tp: Dar al-Lisan . T.th), h. 521

${ }^{5}$ Ar-Raghib al-Asfahani. Al-mufradat fi Gharib al-Quran, (T.tp: T.p. T.th), Hlm.100. Lihat juga Muhammad Chirzin, Jihad dalam Alquran Telaah Normatif, Historis, dan Prospektif, (Yogyakarta: Mitra Pustaka, 1997), h. 2.

${ }^{6}$ Ibn 'ajar al-‘Asqal \pm ni. Fat $¥ u l B \pm r^{3}$, diterjemahkan Amiruddin,(Jakarta: Pustaka Azzam, 2012), juz. XXVI, h. 2

Pengajaran Jihad....

Muhammad Amin 
a. Hadis tentang Jihad dan Perjalanan Hidup Nabi

Pada bab ini ada dua hadis yang di kemukakan oleh Imam Bukhari dan syarahkan oleh Ibn Hajar al-'Asqalani. Hadis pertama adalah :

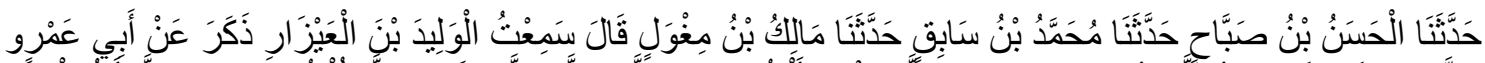

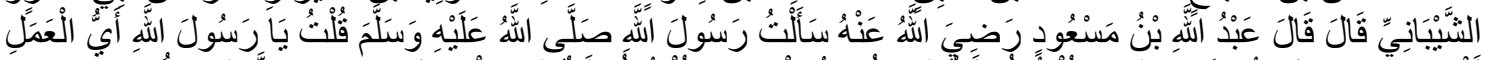

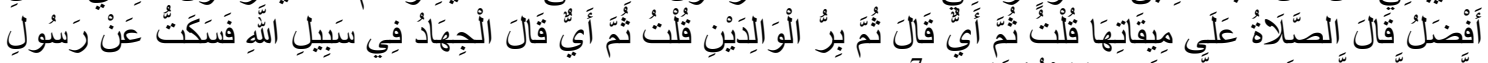

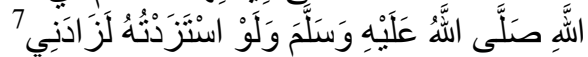

Artinya: Telah bercerita kepada kami Al Hasan bin Shobbah telah bercerita kepada kami Muhammad bin Sabiq telah bercerita kepada kami Malik bin Mighwal berkata; aku mendengar Al Walid bin Al 'Ayzar menyebutkan dari Abu 'Amru Asy Syaibaniy berkata 'Abdullah bin Mas'ud radliallahu 'anhu berkata: "Aku bertanya kepada Rasulullah shallallahu 'alaihi wasallam, aku katakan: "Wahai Rasulullah, amal apakah yang paling utama?" Beliau menjawab: "Sholat pada waktunya". Kemudian aku tanyakan lagi: " Kemudian apa?" Beliau menjawab: "Kemudian berbakti kepada kedua orang tua". Lalu aku tanyakan lagi: "Kemudian apa lagi?" Beliau menjawab: "Jihad di jalan Allah". Maka aku berhenti menyakannya lagi kepada Rasulullah shallallahu 'alaihi wasallam. Seandainya aku tambah terus pertanyaan, Beliau pasti akan menambah jawabannya kepadaku".

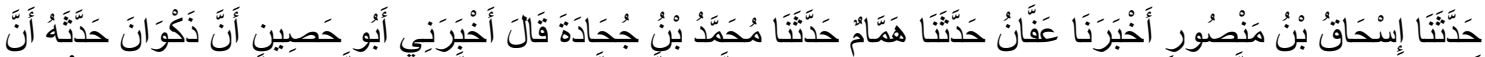

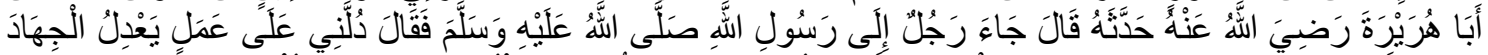

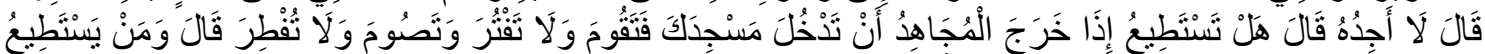

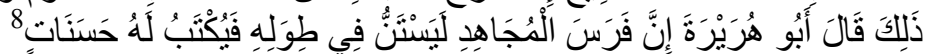

Artinya: Telah bercerita kepada kami Ishaq bin Manshur telah mengabarkan kepada kami 'Affan telah bercerita kepada kami Hammam telah bercerita kepada kami Muhamad bin Juhadah berkata telah bercerita kepadaku Abu Hashin bahwa Dzakwan bercerita kepadanya bahwa Abu Hurairah radliallahu 'anhu bercerita kepadanya, katanya: "Datang seseorang kepada Rasulullah shallallahu 'alaihi wasallam lalu bertanya: "Tunjukkan kepadaku suatu amal yang dapat menyamai jihad?" Beliau menjawab: "Aku tidak menemukannya ". Beliau melanjutkan: "Apakah kamu sanggup jika seorang mujahid keluar berjihad sedangkan kamu masuk ke dalam masjidmu lalu kamu tegakkan ibadah tanpa henti dan kamu berpuasa tanpa berbuka?" Orang itu berkata: "Mana ada orang yang sanggup berbuat begitu". Abu Hurairah radliallahu 'anhu berkata: "Sesunguhnya kuda seorang mujahid yang dikekang talinya untuk berperang akan ditulis sebagai kebaikan".

b. Hadis tentang Manusia yang paling utama adalah mukmin yang berjihad di jalan allah dengan diri dan hartanya.

Pada bab ini ada dua hadis yang akan di bahas :

${ }^{7}$ Abu Abdillah Muhammad bin Ismail al-Bukh $\pm \mathrm{r}^{3} . \phi a ¥^{3} ¥ a l-B u k h \pm r^{3}$, (Beirut: Dar al-Mutabi' Sya'bi, T.th), Juz. III dalam kitab. Jihad, bab : Fadlul jihad wa as-Sir. Nomor hadis. 2574, h. 235.

${ }^{8}$ Abu Abdillah Muhammad bin Ismail al-Bukh $\pm \mathrm{r}^{3}$. ca¥3¥...Ibid, Juz. III dalam kitab. Jihad, bab : Fadlul jihad wa as-Sir. Nomor hadis.2577, h. 236. 


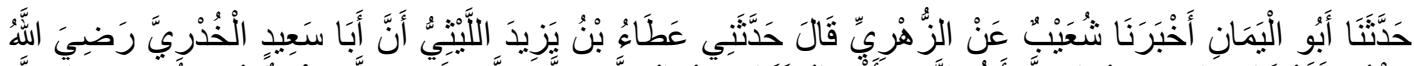

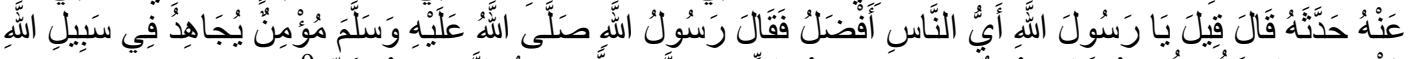

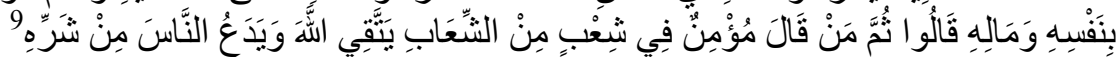

Artinya: Telah bercerita kepada kami Abu Al Yaman telah mengabarkan kepada kami Syu'aib dari Az Zuhriy berkata telah bercerita kepadaku 'Atha' bin Yazid Al Laitsiy bahwa Abu Sa'id Al Khudriy radliallahu 'anhu bercerita kepadanya, katanya: "Ditanyakan kepada Rasulullah, siapakh manusia yang paling utama?" Maka Rasulullah shallallahu 'alaihi wasallam bersabda: "Seorang mu'min yang berjihad di jalan Allah dengan jiwa dan hartanya". Mereka bertanya lagi: "Kemudian siapa lagi?" Beliau menjawab: "Seorang mu'min yang tinggal diantara bukit dari suatu pegunungan dengan bertaqwa kepada Allah dan meninggalkan manusia dari keburukannya".

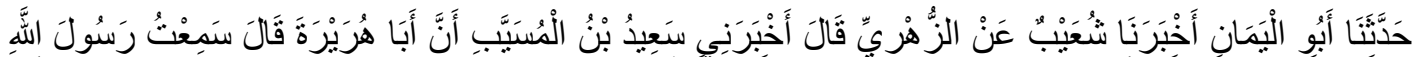

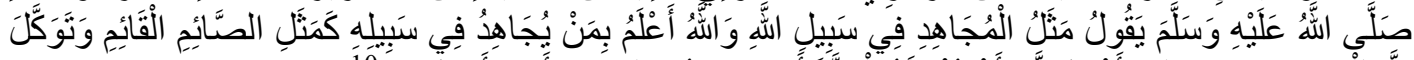

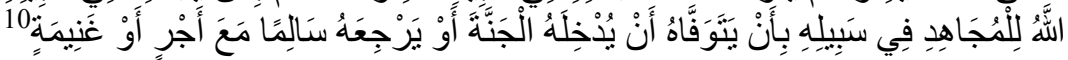

Artinya: Telah bercerita kepada kami Abu Al Yaman telah mengabarkan kepada kami Syu'aib dari Az Zuhriy berkata telah bercerita kepadaku Sa'id bin Al Musayyab bahwa Abu Hurairah radliallahu 'anhu berkata; Aku mendengar Rasulullah shallallahu 'alaihi wasallam bersabda: "Perumpamaan seorang mujahid di jalan Allah, dan hanya Allah yang paling tahu siapa yang berjihad di jalan-Nya, seperti seorang yang melaksanakan shoum (puasa) dan berdiri (shalat) terus menerus. Dan Allah berjanji kepada mujahid di jalan-Nya, dimana bila Dia mewafatkannya maka akan dimasukkannya ke surga atau bila Dia mengembalikannya dalam keadaan selamat dia akan pulang dengan membawa pahala atau ghonimah (harta rampasan perang) ".

\section{Makna Pengajaran Jihad dalam Kitab Fath al-Bari}

a. Kajian tentang bab keutamaan Jihad dan (Siyar) perjalanan hidup Nabi SAW.

Kata siyar merupakan bentuk jamak dari kata sirah (perjalanan hidup). Kata tersebut di gunakan pada bab-bab tentang jihad dengan maksud menerangkan perjalanan hidup Nabi SAW dalam setiap peperangan yang dilakukannya. Pada hadis pertama ini membicarakan tentang ayat Alquran surat at-Taubah ayat 111 dan 112 yang membicarakan tentang peperangan sebagaimana redaksi hadisnya sebagai berikut:

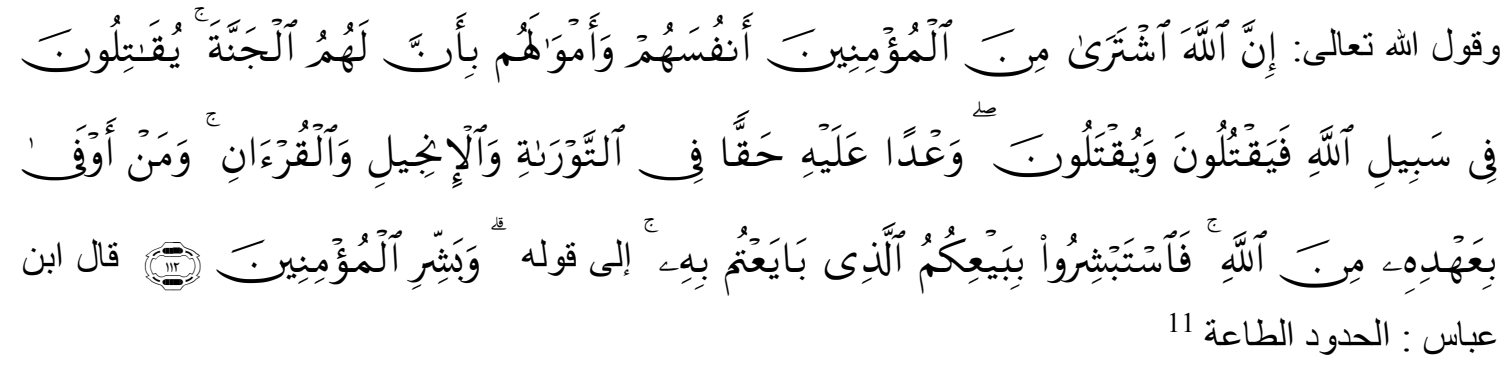

${ }^{9}$ Abu Abdillah Muhammad bin Ismail al-Bukh $\pm \mathrm{r}^{3}$. Ła¥¥¥...Ibid, dalam kitab. Jihad, bab : Afdal an-Nas Mu'min Mujahid binafsihi wa maluhu fi Sabilillah. Nomor hadis.2578. h. 236

${ }^{10}$ Abu Abdillah Muhammad bin Ismail al-Bukh $\pm \mathrm{r}^{3}$. $\notin a ¥^{3} ¥$...Ibid dalam kitab. Jihad, bab : Afdal an-Nas Mu'min Mujahid binafsihi wa maluhu fi Sabilillah. Nomor hadis. 2579, h. 236.

${ }^{11}$ Ibn 'ajar al-'Asqal \pm ni, Fathul ..., h. 3

Pengajaran Jihad. Muhammad Amin 
Artinya: Dan Firman Allah: “ Sesungguhnya Allah telah membeli dari orang-orang mukmin diri dan harta mereka dengan memberikan surga untuk mereka. mereka berperang pada jalan Allah; lalu mereka membunuh atau terbunuh. (Itu telah menjadi) janji yang benar dari Allah di dalam Taurat, Injil dan Al Quran. dan siapakah yang lebih menepati janjinya (selain) daripada Allah? Maka bergembiralah dengan jual beli yang telah kamu lakukan itu......hingga firman-Nya.... dan gembirakanlah orang-orang mukmin itu. Ibnu 'Abbas berkata: "Al-Hudud artinya Ketaatan".

Dalam konteks hadis ini, Ibn Hajar menampilkan beragaman redaksi hadis yang diriwayatkan. Redaksi di atas merupakan riwayat dari an-Nasafi dan Ibn Syibawaih. Sementara dalam riwayat al-Ashili dan Karimah kedua ayat tersebut disebutkan secara lengkap. Kemudian dalam riwayat Abu Zar disebutkan sampai وَعْدَا عَلَيَهْ حَقََّّا (janji

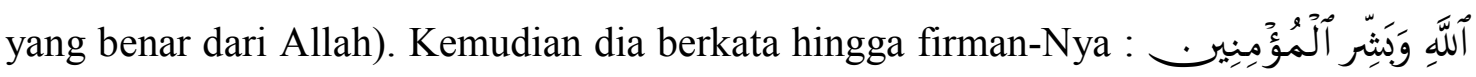

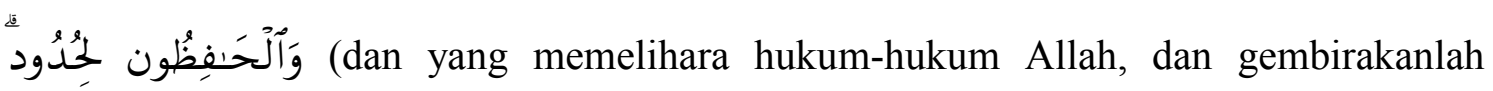
orang-orang mukmin itu.

Tujuan dari menampilkan beragam bentuk riwayat dengan potongan ayat-ayat ini kelihatannya Ibn Hajar bertujuan agar pembaca mengetahui bahwa ada beragam jalur yang meriwayatkan hadis ini, disamping beragam redaksi yang di tampilkan. Hal ini bertujuan untuk memperluas cakrawala pembaca dengan beberapa pendapat dalam meriwayatkan hadis yang di maksud. ${ }^{12}$

Ibn Hajar berpendapat bahwa maksud jual beli pada ayat di atas adalah jual beli yang dilakukan kaum Ansar pada malam (baiat) Aqabah, atau mungkin lebih luas dari itu. Adapun maksud kata قال ابن عباس : الحدود الطاعة, menurut Ibn 'Abbas kata hudud artinya ketaatan. Asar Ibn 'Abbas ini disebutkan melalui sanad yang mausul oleh Abi Hatim dari Ali bin Abi Thalhah dari Ibn 'Abbas berkenaan dengan firman Allah, آله تلك حِدُودِ (itulah batasan-batasan Allah), dia berkata “yakni Taat kepada Allah”. Seakanakan penafsiran ini berdasarkan konsekwensi lafaz. Sebab orang yang taat tidak akan melanggar batasan dan selalu melaksanakan perintah dan menjauhi larangan.

Adapun makna أَيٌْ الْعَمَلِ أَفْضَنْ (Apakah perbuatan yang paling utama). Ibn Hajar mengemukakan pendapat Ad-Daudi yang menurut Ibn Hajar terkesan ganjil. Menurutnya ad-Daudi, "Jika seseorang melaksanakan shalat pada awal waktunya maka jihad lebih didahulukan daripada berbakti kepada kedua orang tua, tapi bila diakhirkan maka berbakti kepada orang tua lebih didahulukan daripada jihad". Namun kata Ibn Hajar saya tidak mengetahui apa yang mendasari pandangannya dalam hal yang demikian.

Menurut Ibn Hajar bahwa shalat disebutkan lebih dahulu daripada jihad dan berbakti kepada orang tua, karena shalat adalah kewajiban bagi mukallaf dalam setiap

\footnotetext{
${ }^{12}$ Ibn 'ajar al-‘Asqal \pm ni. Fathul.,... h. 6.
} 
kondisi. Sedangkan berbakti kepada orang tua disebutkan lebih dahulu daripada jihad, karena jihad itu tergantung izin orang tua. ${ }^{13}$

Sedangkan menurut ath-Thabari, "Nabi SAW menyebut tiga perkara ini secara khusus, karena ketiganya merupakan tanda dan ciri bagi ketaatan yang lain. Barangsiapa yang melalaikan shalat Fardu hingga keluar waktunya tanpa ada uzur, padahal shalat itu sangat ringan dan keutamaannya sangat besar, maka dapat dipastikan dia lebih melalaikan kewajiban yang lain. Barangsiapa yang tidak berbakti kepada kedua orang tua, padahal hak keduanya begitu besar maka tentu dia lebih tidak berbakti kepada orang lain. Barangsiapa meninggalkan jihad memerangi orang Kafir, padahal permusuhan mereka sangat keras terhadap agama Islam, tentu dia akan lebih meninggalkan jihad melawan orang-orang fasik. Maka jelas barangsiapa memelihara ketiga perkara ini, dia akan memelihara pula ketaatan-ketaatan yang lain, dan demikian sebaliknya. $^{14}$

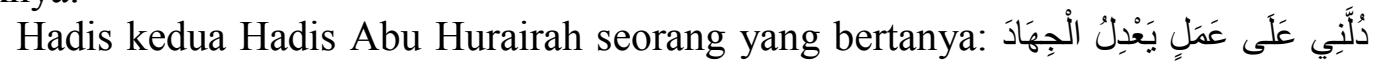
(mengenai tunjukan amalan yang sebanding dengan jihad). Ibn Hajar belum mengetahui siapa yang bertanya tersebut. Ibn Hajar juga menampilkan dalam riwayat Imam Muslim melalui jalur Suhail bin Abi Salih dari Bapaknya disebutkan :

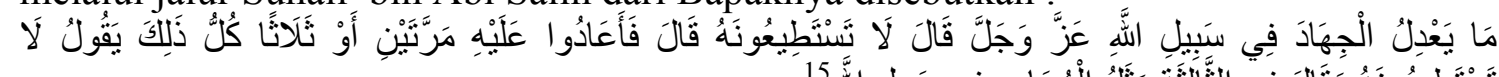

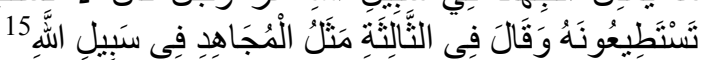

Artinya: (Dikatakan, "Apakah yang sebanding dengan jihad ?. beliau bersabda, "Kalian tidak sanggup melakukannya". Mereka kembali menyakan hal itu kepada beliau dua atau tiga kali. Setiap kali di Tanya beliau menjawab: "kalian tidak akan sanggup melakukannya. Kemudian pada kali ketiga beliaubersabda (perbuatan) yang serupa dengan jihad di jalan Allah...).

Lalu Ibn Hajar mengaitkan hadis ini dengan hadis yang dinukilkan oleh Tirmizi, Ibn Majah dan Ahmad :

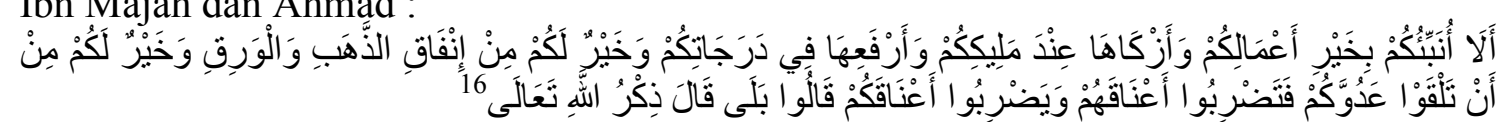

Artinya: Maukah aku beritahukan kepada kalian mengenai amalan kalian yang terbaik, dan yang paling suci di sisi Raja (Allah) kalian, paling tinggi derajatnya, serta lebih baik bagi kalian daripada menginfakkan emas dan perak, serta lebih baik bagi kalian daripada bertemu dengan musuh kemudian kalian memenggel leher mereka dan mereka memenggal leher kalian?" Mereka berkata; ya. Beliau berkata: "Berdzikir kepada Allah ta'ala."

Menurut Ibn Hajar kemusykilan terjadi karena secara zahir zikir dapat menyamai semua yang dilakukan Mujahid dan lebih utama daripada infak, Padahal jihad dan member nafkah memiliki manfaat yang tidak terbatas pada pelakunya. Dengan

${ }^{13}$ Ibn 'ajar al-‘Asqal \pm ni. Fathul.,... h. 7.

14 Ibn \ajar al-`Asqal \pm ni. Fat¥ul...Ibid, Hlm. 6 Lihat juga Salman al-Audah, Jihad Sarana Menghilangkan Ghurbah Islam, diterjemahkan oleh Kathur Suhardi, (Jakarta: Pustaka al-Kautsar, 1992), h. 99

${ }^{15} \mathrm{Im} \pm \mathrm{m}$ Abi Husein Muslim bin Hajjaj al-Qusayri an-Naisaburi. Sa¥3¥ Muslim bi Syarh Imam an-Nawawi, (Cairo: Al-Mathba'ah al-Misriyah, T.th), Kitab Nikah, Bab Fadhlul Syahadah fi Sabilillah Ta'ala. Nomor Hadis. 3490, h. 324.

${ }^{16}$ Abi Isa Muhammadbin Isa bin Tsaurah at-Tirmizi, Sunan at-Tirmizi, (Mesir: Syarikah Maktabah wa al-Mathba'ah Musthafa al-Babi al-Halabi, 1968), bab Afdal az-Zikr, Nomor Hadis. 3299, h. 138.

Pengajaran Jihad. Muhammad Amin 
mengutip pendapat Iyadh yang mengatakan Hadis pada bab ini menerangkan tentang keutamaan jihad, hingga semua keadaan dan tindak tanduk Mujahid yang bersifat mubah dapat menyamai pahala orang yang terus shalat dan lainnya. Oleh karena itu, Nabi bersabda "Engkau tidak akan mampu melakukannya".

Hadis ini juga mengandung faidah bahwa keutamaan tidak dapat diketahui berdasarkan logika, bahkan ia adalah karunia dari Allah swt kepada siapa saja yang dikehendaki-Nya. Kemudian hadis ini dijadikan dalil bahwa jihad merupakan perbuatan utama secara mutlak. ${ }^{17}$ Selanjutnya, Ibn Hajar memaparkan pendapat Ibn Daqaqiq bahwa secara logika dapat diterima jihad merupakan perbuatan paling utama diantara perbuatan-perbuatan yang bersifat sebagai sarana. Karena jihad merupakan sarana untuk meninggikan agama, menyebarkannya dan memadamkan kekufuran serta menghancurkannya. Maka keutamaan jihad sesuai dengan keutamaan hal-hal tersebut.

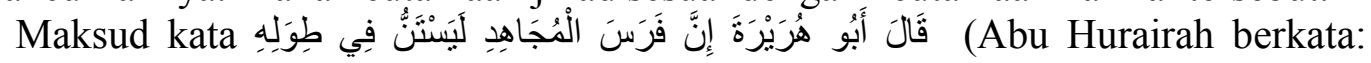
"sesungguhnya kuda Mujahid bergerak pada tali pengikatnya...), Maksudnya melonjatloncat dengan tangkas. Dalam mengupas arti kalaimat ini Ibn Hajar mengambil pendapat al-Jauhari, yang mengatakan makna "layastanmu" adalah mengangkat kakinya lalu menjatuhkannya secara bersamaan. Pakar bahasa memahaminya kata ini adalah kuda itu masuk ke tengah musuh dan bergerak kesana kemari.

Dalam perumpamaan disebutkan Istannat al Fishaal hatta qar'aa (anak kuda meloncat hingga mencapai kuda pejantan). Perumpamaan ini sebagai ungkapan bagi seseorang yang hendak menyamai orang yang berada di atasnya.

Adapun makna kalimat فِي طِوَلِله adalah tali yang digunakan mengikat hewan, dan dipegang ujungnya serta dilepaskan ditempat merumput.

Maksud kalimat فَكَكْتَبُ لَهُ حَسَنَاتٍ (ditulis untuknya kebaikan-kebaikan), maksudnya setiap gerakan kuda itu ditulis sebagai kebaikan bagi mujahid. Kalimat ini disebut oleh Abu Husain dari Abu Shalih secara mauquf. ${ }^{18}$

b. Syarah hadis Manusia yang paling utama adalah mukmin yang berjihad di jalan Allah dengan diri dan hartanya

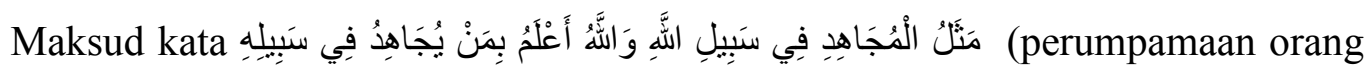
yang berjihad di jalan Allah, dan Allah lebih tahu siapa yang berjihad di jalan-Nya). Hal ini berkaitan dengan kewajiban berangkat berperang. Menurut 'Ibn Hajar di sini terdapat isyarat agar memperhatikan keiikhlasan. Kewajiban berangkat beserta dengan niat berperang. Ibn Hajar mengatakan bahwa ada dua masa dalam berjihad, yaitu masa Nabi SAW dan masa sesudahnya. Pada masa Nabi disyariatkan berperang setelah hijrah ke Madinah, maka apakah hukumnya fardu 'ain atau fardhu kifayah.

Menurut al-Mawardi hukumnya fardhu 'ain bagi kaum Muhajirin dan bukan selain mereka. Hal ini dikuat oleh kewajiban berhijrah ke Madinah sebelum pembebasan kota Mekkah bagi setiap yang masuk Islam demi membela Islam. Sedang as-Suhaili berpendapat bahwa fardu 'ain bagi kaum Ansar dan bukan bagi kaum selainnya. Hal ini didukung oleh sikap mereka yang berbai'at kepada Nabi SAW pada malam Aqabah, dimana mereka berjanji untuk melindungi Rasulullah dan membelanya.

Dari perkataan keduanya disimpulkan bahwa jihad adalah fardhu 'Ain bagi kaum Muhajirin dan Ansar dan bukan bagi selain mereka. Meskipun demikian, jihad

\footnotetext{
${ }^{17}$ Ibn 'ajar al-‘Asqal \pm ni. Fat¥ul...., h. 10

${ }^{18}$ Ibn ajar al-‘Asqal \pm ni. Fat¥ul....,h. 11
} 
bukan fardhu 'ain bagi kelompok itu secara mutlak, bahkan menjadi fardhu 'ain bagi kaum Ansar jika ada yang hendak menyerang kota Madinah, dan fardhu 'ain bagi kaum Muhajirin jika Nabi SAW hendak menyerang orang-orang Kafir. Hal ini didukung oleh pristiwa Badar, Uhud dan lain-lainnya. ${ }^{19}$

Sedangkan jihad setelah masa Nabi SAW hukumnya fardhu kifayah menurut pandangan yang mashur. Jika kondisi mendesak seperti musuh telah memasuki wilayah kaum muslimin, maka hukumnya menjadi fardhu 'ain. Sebagian berpendapat bahwa jihad hukumnya wajib selama seseorang itu memungkinkan untuk melakukannya dan dalam keadaan kuat. Namun kata Ibn Hajar pendapat yang lebih tepat adalah hukum jihad tetap berlangsung sebagaimana pada masa Nabi hingga terjadi pembebasan negeri-negeri Islam telah tersebar di seluruh pelosok, kemudian hukum itu beralih kepada dijelaskan di atas. Kesimpulannya bahwa jihad kepada orang Kafir adalah fardhu 'ain bagi setiap muslim, baik dengan tangan (kekuatan), lisan, harta maupun hati. $^{20}$

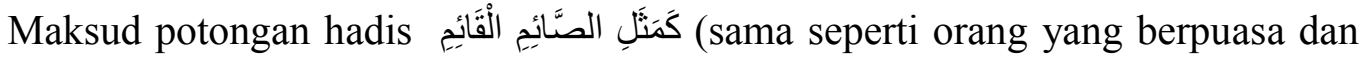
berdiri (shalat). Dalam memahami potongan hadis ini Ibn Hajar juga menampilkan beberapa riwayat dari Imam yang lain, dalam rangka menampilkan ragam dalam periwayatan hadis ini, seperti riwayat Imam Muslim dari Abu Shalih dari Abu Hurairah (Seperti orang yang berpuasa yang shalat dan berdiri (membaca) ayat-ayat Allah, tidak berhenti shalat dan puasanya). ${ }^{21}$ Kemudian an-Nasa'i memberi tambahan dalam riwayatnya melalui jalur ini, الْخَاثِعِ الرَّاكِع السَّاجِد

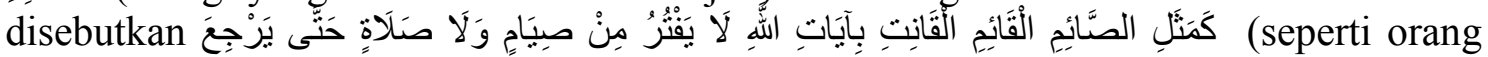
yang puasa dan shalat terus menerus, yang tidak berhenti puasa dan shalat hingga ia (orang-orang berjihad) kembali. ${ }^{23}$ Selanjutnya Ibn Hajar juga mengemukakan riwayat Anmad dan Bazzar dari Hadis an-Nukman bin Basyir dari Nabi SAW disebutkan

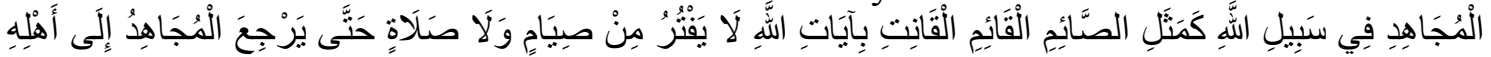
(Permisalan orang yang berjihad di jalan Allah adalah seperti seorang yang puasa di siang hari dan shalat di malam hari membaca ayat ayat Allah, dia tidak putus puasa dan shalatnya sehingga seorang mujahid pulang ke rumah keluarganya".. ${ }^{24}$

Mengomentari hal di atas, Ibn Hajar mengatakan keadaan orang yang berpuasa dan shalat disamakan dengan keadaan orang yang berjihad di jalan Allah dalam mendapatkan pahala disetiap gerak dan diamnya. Karena yang dimaksud dengan orang yang berpuasa dan shalat adalah orang yang tidak pernah berhenti ibadah sehingga pahalanya terus menerus. Demikian pula orang yang berjihad, tidak sesaatpun waktunya yang tersia-siakan tanpa ada pahala, berdasarkan keterangan dalam hadis "Sesungguhnya seorang mujahid, setiap gerak kudanya ditulis kebaikan-kebaikan untuknya". Hal ini di jelaskan lagi oleh Alquran surat at-Taubah ayat 120.

19 Ibn 'ajar al-‘Asqal \pm ni. Fat¥ul...., h. 109-110.

${ }^{20}$ Ibn ’ajar al-‘Asqal \pm ni. Fat¥ul...., h. 110

${ }^{21} \mathrm{Im} \pm \mathrm{m}$ Abi Husein Muslim bin Hajjaj al-Qusayri an-Naisaburi. Sa¥3¥ Muslim....Ibid, Kitab Jihad, bab Fadl as-Syahadah fi Sabilillah Ta'ala, no Hadis 3490, h. 79.

${ }^{22} \mathrm{Abu}$ 'Abdurrahman Ahmad bin Syu'ib bin 'Ali bin Bahar bin Sinan an-Nasa'I, Sunan anNasa'I, (Beirut: Dar al-Fikr, 1930), Kitab Jihad, Bab Masal al-Mujahid fi Sabilillah 'Azza wa jalla, No. Hadis. 3076, h. 173.

${ }^{23}$ Imam Malik, Muawwat Imam Malik, (Beirut: Dar al-Fikr, 1990), Kitab Jihad, Bab at-Targhib fi al-Jihad, No Hadis. 849, h. 243.

24 Ahmad bin Muhammad bin Hanbal, Musnad Ahmad bin Hanbal, (Beirut: Dar al-Fikr, T.th), Bagian Musnad Abu Hurairah, No. Hadis. 9116. h. 342.

Pengajaran Jihad.... Muhammad Amin 
Kesimpulan dari kandungan hadis-hadis di atas adalah realisasi janji Allah dalam firman-Nya surat At-Taubah ayat 111 di atas. Realisasi tersebut berupa karunia dari-Nya. Rasulullah SAW telah mengemukakan karunia Allah berupa pahala dengan lafaz "Memberi jaminan" dan yang sepertinya, sesuai kebiasaan mereka.

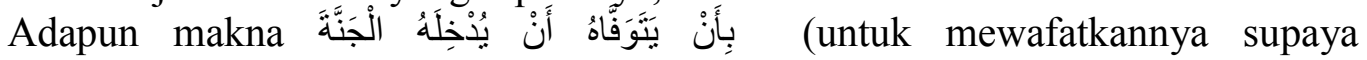
memasukkannya ke dalam surga). Maksudnya Allah akan memasukannya ke dalam Surga apabila Dia mewafatkannya. Ibn Hajar menyertakan riwayat Abu Zur'ah adDimasqi dari al-Yaman disebutka انْ نَوَفَّاهُ (jika Allah mewafatkanya). Yakni menggunakan kata bersyarat disertai kata kerja yang menunjukkan waktu masa lampau. $^{25}$

Potongan kata أَنْ يُنْخِلَهُ الْجَنَّنَ (untuk memasukan ke dalam Surga). Maksudnya tanpa hisab dan azab, atau Allah memasukannya ke dalam Surga saat kematiannya,

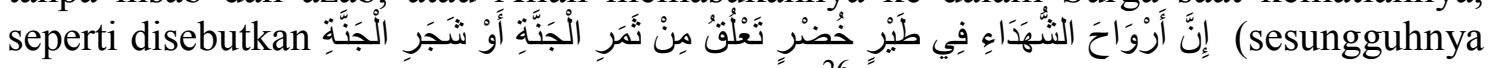
ruh-ruh para syuhada beterbangan di Surga). ${ }^{26}$ Berdasarkan keterangan ini, maka pernyataan mereka yang mengatakan bahwa "makna zahir hadis tersebut adalah menyamakan antara orang yang mati syahid dan orang yang kembali dengan selamat karena pahala yang didapat mengharuskan masuk Surga", tidak dapat diterima. Sebagai jawabannya dikatakan bahwa yang dimaksud "masuk Surga bagi yang syahid" adalah masuk secara khusus.

Adapun potongan kalimat مَعَ أَجْرِ أَوْ غَنْيمَة (Bersama pahala atau rampasan perang). Maksud dari kalimat ini bersama pahala saja bila tidak mendapatkan harta rampasan sedikitpun, atau bersama rampasan perang disertai pahala. Seakan Nabi tidak menyinggung tentang pahala kedua yang disertai rampasan perang, sebab pahala ini lebih kecil dibandingkan dengan pahala yang tidak disertai rampasan.

Ibn Hajar menyatakan bahwa faktor yang melahirkan penakwilan ini adalah makna zahir hadis yang menyatakan bahwa apabila mendapatkan harta rampasan perang maka tidak akan mendapatkan pahala. Namun bukan demikian yang di maksud, bahkan maksudnya adalah mendapat rampasan perang disertai pahala yang lebih sedikit di banding pahala mereka yang tidak mendapat rampasan perang, sebab kaidah dasar menyatakan jika tidak ditemukan rampasan perang maka pahala yang didapat lebih utama dan sempurna. Hadis ini dengan tegas menafikan rampasan perang dan tidak menafikan adanya pahala bersama rampasan perang sekaligus. ${ }^{27}$

Ibn Hajar memperkuat pendapatnya dengan mengambil pendapat al-Kirmani yang mengatakan:'Makna hadis adalah bahwa seorang Mujahid memiliki dua kemungkinan: Mati syahid atau kembali dengan selamat. Jika kembali dengan selamat, maka ia akan mendapatkan rampasan perang atau pahala atau mungkin mendapatkan rampasan perang dan pahala sekaligus. Perkara yang dinafikan di sini adalah hilangnya kedua hal itu, bukan kemungkinan didapatkannya kedua hal itu sekaligus". ${ }^{28}$

Ibn Hajar juga tidak lupa menyoroti makna kata "au" dan "wa" sebagai kata penghubung pada hadis yang serupa dengan ini, dengan mengemukakan beberapa pemahaman ulama dan redaksi-redaksi hadis yang beragam. Salah satunya adalah ada di kalangan ulama yang memahami kata "au" (atau) pada hadis ini bermakna "dan". Hal ini seperti yang di benarkan oleh Ibn Abdil Barr dan al-Qurtubi dan di sokong oleh at-

\footnotetext{
${ }^{25}$ Ibn 'ajar al-'Asqal \pm ni. Fathul...., h. 18.

26 Imam at-Tirmizi, Sunan...Ibid, Kitab Jihad, Bab ma ja'a fi sawab asy-Syuhada, No
} Hadis. 1565 , h. 89.

${ }^{27}$ Ibn 'ajar al-'Asqal \pm ni. Fathul..., h. 19

${ }^{28}$ Ibn ajar al-'Asqal \pm ni. Fathul..., h. 19 
Turabisyti, sehingga makna hadis menurut pandangan ini adalah "kembali dengan pahala dan rampasan perang". ${ }^{29}$

Selanjutnya Ibn Hajar menampilkan bahwa kata penghubung “dan” pada kalimat itu tercantum pula dalam riwayat Imam Muslim dari Jalur al-A'raj dari Abu Hurairah. Demikian pula diriwayatkan dari Yahya bin Yahya dari Mughirah bin Abdurrahman dari Abu al-Zinad. Namun Ja'far al-Firyabi dan sejumlah periwayat dari Yahya bin Yahya meriwayatkan dengan lafaz, أَجْرِ أَوْ غَنَيمَة (pahala atau rampasan perang), yakni menggunakan kata penghubung "au" (atau). Demikian juga Imam Malik dengan menggunakan kata yang sama. Perbedaan hanya terjadi dari Jalur Yahya bin Bukai dari Malik dengan menggunakan kata "wa", dalam hal ini riwayat Yahya bin Bukair masih diperdebatkan.

Adapun riwayat an-Nasa'I melalui az-Zuhri dari Sa'id bin al-Musayyab dari Abu Hurairah, menggunakan kata penghubung "dan". Demikian juga riwayat Abu Dawud dari Jalur Abu Umamah. Jika riwayat-riwayat ini akurat, maka harus di pahami bahwa "au" pada hadis tersebut bermakna "dan", sebagaimana pendapat ahli bahasa dari Kufah.

Ibn Hajar memberikan analisis bahwa jika kata "au" dalam hadis tersebut bermakna "dan" maka konsekwensinya dari segi makna bahwa Allah menjamin bagi setiap yang kembali dari peperangan akan mendapat dua hal itu sekaligus (pahala dan rampasan perang). Padahal berapa banyak mereka yang kembali dari peperangan tanpa membawa harta rampasan peperangan sedikitpun. Secara lahiriah bahwa orang yang kembali tanpa membawa harta rampasan perang berarti tidak mendapatkan pahala, seperti halnya bahwa setiap orang yang berperang akan mendapatkan pahala dan rampasan perang sekaligus. ${ }^{30}$

Sementara dalam riwayat Imam Muslim dari riwayat Abdullah bin Amr bin Ash dari Nabi SAW :

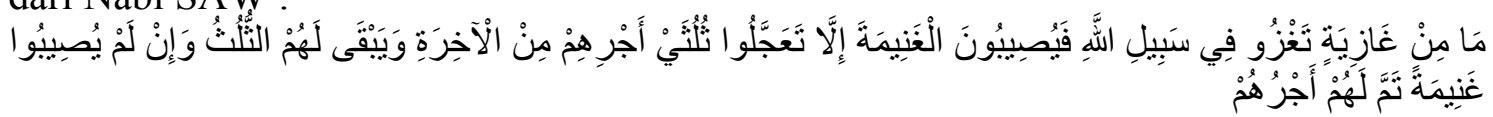

(Tidak ada suatu pasukan yang berperang di jalan Allah, kemudian mereka mendapatkan rampasan perang melainkan mereka telah mengambil terlebih dahulu dua pertiga dari pahala mereka di akhirat dan tersisa sepertiganya, jika mereka tidak mendapatkan rampasan perang, maka mereka mendapatkan pahala secara sempurna). ${ }^{31}$

Ibn Hajar menampilkan riwayat Muslim ini dalam rangka mengukuhkan penakwilan yang pertama, bahwa yang mendapat rampasan perang juga mendapat pahala, tetapi pahala mereka lebih sedikit di banding dengan pahala yang tidak mendapat harta rampasan perang. Untuk itu kata Ibn Hajar, harta rampasan perang menjadi imbalan sebagian pahala mengikuti perang. Jika pahala orang yang mendapatkan rampasan perang dan kenikmatan duniawi yang dia dapatkan dihadapkan dengan pahala orang yang tidak mendapatkan harta rampasan perang- padahal keduaduanya sama-sama mengalami dan merasakan kelelahan dan kesulitan- maka pahala orang yang mendapatkan harta rampasan perang lebih kecil disbanding pahala orang yang tidak mendapat harta rampasan perang. Hal ini sesuai dengan perkataan al-

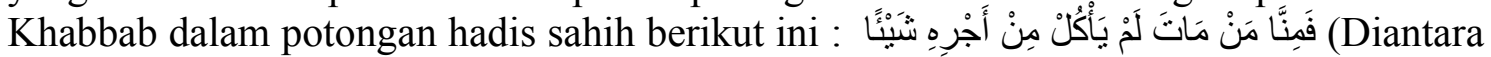
kami ada yang meninggal dunia sebelum memakan sedikitpun pahalanya (imbalannya).

\footnotetext{
${ }^{29}$ Ibn lajar al-'Asqal \pm ni. Fat $¥ u l \ldots . .$, h. 19

${ }^{30}$ Ibn 'ajar al-‘Asqal \pm ni, Fathul...., h. 20-21

${ }^{31}$ Imam Muslim, Sahih....Ibid, Kitab jihad tentang Bayan Qadar sawab min ghaza fa ghanam wa man yughnam, no hadis.3528, h .79 
Di akhir penjelasannya Ibn Hajar mengkritik pendapat ulama yang mengatakan bahwa ada kemusykilan sehubungan dengan berkurangnya pahala orang yang berperang dengan sebab mendapatkan harta rampasan perang, dimana hal ini menyalahi indikasi sejumlah hadis. Bahkan Nabi SAW memuji tentang kehalalan harta rampasan perang dan menjadikannya sebagai keutamaan umatnya. Sekirannya hal itu mengurangi pahala, tentu tidak patut mendapat pujian. Disamping itu, konsekwensinya pahala mereka yang turut dalam perang Badar lebih sedikit disbanding pahala mereka yang turut dalam perang Uhud, padahal mereka yang turut dalam perang Badar lebih utama menurut kesepakatan ulama.

Ibn Hajar juga mengkritik pendapat ulama yang mengatakan bahwa rampasan perang yang mengurangi pahala adalah khusus bagi mereka yang menjadikan rampasan perang sebagai motivasi utama, sedangkan kesempurnaan pahala khusus bagi mereka yang ikhlas dalam berjihad. Menurut Ibn Hajar pendapat ini kurang tepat, karena di bagian awal hadis disebutkan bahwa kedua kelompok ini sama-sama ikhlas dalam

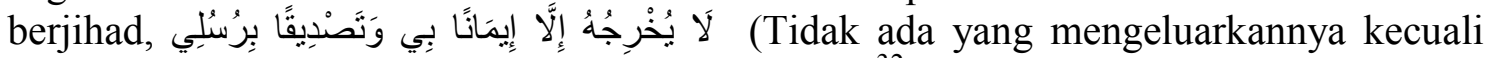
iman kepada-Ku dan membenarkan rasul-rasul-Ku). ${ }^{32}$

\section{PENUTUP}

Ibn Hajar al-'Asqalani dalam kitab Fath al-Bari menulis jihad adalah mengerahkan segala kemampuan untuk memerangi kaum Kafir. Lebih lanjut ia menjelaskan bahwa jihad juga digunakan dalam arti melawan hawa nafsu, Syaitan dan orang Fasik. Jihad melawan hawa nafsu adalah dengan belajar masalah agama, mengamalkan dan mengajarkannya. Sedangkan jihad melawan Syaitan adalah menolak semua apa (syubhat dan hawa nafsu) yang dibisikannya. Adapun jihad dalam arti melawan orang Kafir dapat dilakukan dengan kekuatan harta, lisan, dan hati. Sementara jihad melawan orang fasik adalah dengan kekuatan lisan dan hati.

Hukum jihad pada masa Nabi adalah fardhu 'Ain bagi kaum Muhajirin dan Ansar dan bukan bagi selain mereka. Meskipun demikian, jihad bukan fardhu 'ain bagi kelompok itu secara mutlak, bahkan menjadi fardhu 'ain bagi kaum Ansar jika ada yang hendak menyerang kota Madinah, dan fardhu 'ain bagi kaum Muhajirin jika Nabi SAW hendak menyerang orang-orang Kafir. Sedangkan jihad setelah masa Nabi SAW hukumnya fardhu kifayah menurut pandangan yang mashur. Jika kondisi mendesak seperti musuh telah memasuki wilayah kaum muslimin, maka hukumnya menjadi fardhu 'ain. Sebagian berpendapat bahwa jihad hukumnya wajib selama seseorang itu memungkinkan untuk melakukannya dan dalam keadaan kuat. Kesimpulannya bahwa jihad kepada orang Kafir adalah fardhu 'ain bagi setiap muslim, baik dengan tangan (kekuatan), lisan, harta maupun hati.

Ibn Hajar dalam mengupas permasalahan jihad sering membandingkan satu riwayat dengan riwayat yang lain dengan perbedaan redaksi yang berbeda sedikit, demikian juga pendapat ulama syarah yang beragam. Tujuan dari pemaparan ini untuk memperluar cakwarala dan mengkaji sebuah hadis.

${ }^{32}$ Imam Ahmad bin Hanbal, Musnad...Ibid, Baǵian Musnad Abu Hurairah, No. Hadis. 8821. 


\section{DAFTAR PUSTAKA}

al-Asfahani, Ar-Raghib. Al-mufradat fi Gharib al-Quran, T.tp: T.p. T.th

al-‘Asqal \pm ni, Ibn ${ }_{\mid}$ajar. Fat $¥ u l B \pm r^{3}$, diterjemahkan Amiruddin, Jakarta: Pustaka Azzam, 2012, juz. XXVI

al-Audah, Salman, Jihad Sarana Menghilangkan Ghurbah Islam, diterjemahkan oleh Kathur Suhardi, Jakarta: Pustaka al-Kautsar, 1992

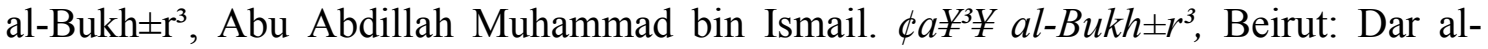
Mutabi' Sya'bi, T.th, Juz. III

Chirzin, Muhammad, Jihad dalam Alquran Telaah Normatif, Historis, dan Prospektif, Yogyakarta: Mitra Pustaka, 1997

Hanbal, Ahmad bin Muhammad bin, Musnad Ahmad bin Hanbal, Beirut: Dar al-Fikr, T.th

Maqluf, Abu Luois, Al-Munjid fi al-Lugah wa al-'alam, Beirut: Dar al-Masriq, 1986

Manzur, Ibn, Lisan al- 'Arab al-Muhith, T.Tp: Dar al-Lisan . T.th

an-Naisaburi, $\operatorname{Im} \pm m$ Abi Husein Muslim bin Hajjaj al-Qusayri. Sa¥¥¥ Muslim bi Syarh Imam an-Nawawi, Cairo: Al-Mathba'ah al-Misriyah, T.th

an-Nasa'I, Abu 'Abdurrahman Ahmad bin Syu'ib bin 'Ali bin Bahar bin Sinan, Sunan an-Nasa'I, Beirut: Dar al-Fikr, 1930

Qardhawi, Yusuf, Pendidikan Islam dan Madrasah Hasan al-Banna, Diterjemahkan Bustami A.Ghani dan Zainal Abidin Ahmad, Jakarta: Bulan Bintang, 1980

at-Tirmizi, Abi Isa Muhammadbin Isa bin Tsaurah, Sunan at-Tirmizi, Mesir: Syarikah Maktabah wa al-Mathba'ah Musthafa al-Babi al-Halabi, 1968 